\title{
Comparative Effect between of Teflubenzuron, Bacillus thuringiensis and Serratia marcescens Individually and Combined on Transaminase Activities of Spodoptera littoralis (Boisd) \\ Abd EL- Naby, S. M.; Saheir F. EL-Lakwah and T. A. A. Elsheikh \\ Plant Protection Research Institute, Agriculture Research Center, Dokki, Giza

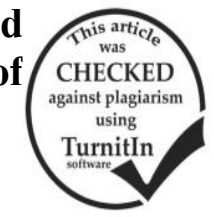

ABSTRACT

The second instars $S$. littoralis larvae were exposed to the $\mathrm{LC}_{50}$ of Teflubenzuron, Bacillus thuringiensis Var. kurstaki. , and the concentration $\left(\mathrm{MC}_{50}\right)$ of Serratia marcescens causes $50 \%$ malformation for pupae, separately and in sequential combined of both $B$. thuringiensis/ S.marcescens $(B t / S m)$ and Teflubenzuron/S.marcescens to compare the effect of the tested pesticides on the aspartate aminotransferase (AST) activity and alanine aminotransferase (ALT) activity during pupal stage of Spodoptera littoralis Boisd. Treatment with $B$. thuringiensis or $S$. marcescens alone revealed generally significant decreases to AST through pupal stage relative to control. The highest levels of (AST) aspartate aminotransferase activities were clearly found in individual treatment with Teflubenzuron. On the other hand, when the sequential combined effect treatment $B$. thuringiensis/ S. marcescens $(B t / S m)$ was used , there were more reduction in the AST activity at $2^{\text {nd }}, 4^{\text {th }}$ and $10^{\text {th }}$ days than that of $S$. marcescens and generally ,during the pupal stage, the sequential $\mathrm{Bt} / \mathrm{Sm}$ had less effect than individual B. thuringiensis . The effect of Teflubenzuron / S. marcescens ((Teflu/Sm) commonly was higher than individual $S$. marcescens but less effective than Teflubenzuron alone. Also, Teflubenzuron had an effect on alanine aminotransferase (ALT) activity higher than B. thuringiensis which was effective than S.marcescence. In contrast, in the sequential combined effect treatments, $B t / S m$ exhibited more decreasing effect at $2^{\text {nd }}, 12^{\text {th }}$ and $14^{\text {th }}$ day of pupation $(-72.93 \%,-82.86 \%$ and $89.56 \%$, respectively ) than treatment with $B$. thuringiensis alone. Teflu/Sm caused significant reduction in alanine aminotransferase activity except at $4^{\text {th }}$ and $6^{\text {th }}$ days, where there is significant increase. The increase at $6^{\text {th }}$ day $(203.56 \%)$ was higher than that of Teflubenzuron alone (126.18\%) or S. marcescens $(47.60 \%)$. But overall, Teflubenzuron alone had the highest effect.

\section{INTRODUCTION}

Spodoptera littoralis Bosid (Lepidoptera: Noctuidae), the Egyptian cotton leaf worm, is a polyphagous foliage feeding insect. It considered as one of the most serious pests of many different Egyptian crops (Magd El- Din \& El-Gengaihi, 2000). It attacks plants in 44 families containing at least 112 species of plants of varying economic importance (Sarto and Monteys, 1988). Now it has become necessary to search for alternative means of pest control which can minimize the use of the synthetic chemicals that cause harmful residues in the food chain and pollution of the surrounding natural enemies and pest resistance. The necessity to find alternative insecticides such as, use insect growth regulators (IGRs). IGR's had been recently grouped in chitin synthesis inhibitors (CSIs) and substances that interfere with the action of insect. hormones (i.e. juvenile hormone analogues, and ecdysteroids) (Tunaz and Uygun, 2004) IGRs are considered to have little human toxicity because humans do not make chitin and do not make or use the hormones insects use in moulting (Schmutterer, 1985)

The present study was undertaken to investigate the effect of Teflubenzuron, Bacillus thuringiensis Var. kurstaki. , and Serratia marcescens separately and in sequential combined of both $B$. thuringiensis/ S.marcescens $(\mathrm{Bt} / \mathrm{Sm})$ and Teflubenzuron/S.marcescens on the aminotransferase ((AST/GOT)) activity and alanine aminotransferase (ALT/GPT) activity during pupal of Spodoptera littoralis

\section{MATERIALS AND METHODS}

\section{Rearing technique}

A stock culture of the cotton leaf worm, Spodoptera littoralis Boisd was obtained from a laboratory strain maintained in the Cotton Pest Research Section, Plant Protection Research Institute, Agriculture Research Center, Dokki, Giza, for several generations without any insecticidal and /or microbial pressure. The insect was reared on castor-oil leaves, Ricinus communis, under laboratory conditions at $25 \pm 2^{\circ} \mathrm{C}$ and $60 \pm 5 \%$ R.H. 2nd and late 6 th instar larvae were used in the present investigation.

Insecticidal

Insect growth regulator (IGR)

Common name: Teflubenzuron, Trade name: No molt, 15 \% S.C., Chemical name: N-[(3, 5-dichloro-2, 4difluorophenyl) aminocarbonyl]-2, 6-difluorobenzamide, Empirical fromula: C14 H6 Cl2 F4 N2 O2, Molecular weight: 381.1, this IGR belong to chitin synthesis inhibitors group and has been obtained from Sumitomo Chemical Co., Ltd.

Protecto

It is a wettable powder formulation, based on Bacillus thuringiensis Var. kurstaki.. It contains lepidopteran toxin $9.4 \%$ produced by the Plant Protection Research Institute, Agricultural Research Center, Dokki, and Cairo, Egypt.

\section{Serratia marcescens}

Chitinase producing bacterial strain belong to genus Serratia was used throughout the current work. The bacterial strain was isolated from Egyptian soils and identified as Serratia marcescens, which was formulated as a biological agent for plant parasitic nematodes. The bioagent is produced and distracted on a commercial scale (Trade name, Nemaless) by Soils, Water and Environ. Res. Inst. ARC, Giza, Egypt.

Toxicity assay

Determination of $\mathrm{LC}_{50}$ values of both Teflubenzuron \& Bacillus thuringiensis

To assess the activity of the two pesticides ; Teflubenzuron \& B. thuringiensis under investigation, a series of six aqueous concentrations were prepared which were $0.625,0.312,0.156,0.078,0.039$ and $0.0195 \mathrm{ppm}$ for Teflubenzuron and $1410,705,352,176,88$ and $44 \%$ for $B$. thuringiensis .Treatment was conducted by the dipping technique according to Abo El-Ghar et al., 1994 where castor oil leaves, Ricinus communis were immersed in one of the prepared concentrations of each of the two tested agents. The leaves then left to dry at room 
temperature before being offered to newly ecdysis $2^{\text {nd }}$ instars $S$. littoralis larvae. Larvae were fed on treated leaves for $48 \mathrm{~h}$, subsequently larvae were fed on untreated castor oil leaves for the following duration of the larval stage. Each treatment comprised 30 larvae and was replicated three times. A similar number of larvae were considered as a control in which larvae were offered castor oil leaves dipped in water. Mortality was recorded daily and accumulative larval mortality was determined at the end of the larval stage. The data were subjected to probit analysis (Finney, 1971) to give LC $_{50}$ values of both Teflubenzuron and B. thuringiensis in probit analysis the raw data of concentration versus mortality $\%$ were transferred to a linear form of log concentration verses $\%$ mortality probability by LDP line program which then transferred the $\log$ concentrations to original concentrations. From the plot we can obtain the $\mathrm{LC}_{50}$ values of Teflubenzuron and $B$. thuringiensis. The Toxicity index of the tested compounds was determined according to Sun (1950).

\section{Determination of $\mathrm{MC}_{50}$ of Serratia marcescens}

For detection the minimal concentration caused $50 \%$ adult malformation $\left(\mathrm{MC}_{50}\right)$, series dilutions of Serratia marcescens $\left(10^{9}, 10^{8}, 10^{7}, 10^{6}\right.$ and $10^{5}$ colony forming unit, cfu / $\mathrm{ml}$.) were prepared. Sawdust was treated with $S$. marcescens $(\mathrm{g} / \mathrm{ml})$ then left to dry at room temperature and offered to late $6^{\text {th }}$ instar larvae, to pupate on it. Larvae pupated on untreated sawdust were used as control. 30 larvae late $6^{\text {th }}$ instar of $S$. littoralis were placed in each glass jar. These jars were incubated at $25^{\circ} \mathrm{C}$ for 14 days. Three replicates per each jar were carried out. The adult malformation percentages were determined.The data were then subjected to probit analysis (Finney, 1971) to obtain the concentration which causes $50 \%$ adult malformation $\left(\mathrm{MC}_{50}\right)$ for $S$. marcescens. The procedure for obtaining $\mathrm{MC}_{50}$ of $S$. marcescens is similar for obtaining $\mathrm{LC}_{50}$ of Teflubenzuron and $B$. thuringiensis except that the concentration was plotted versis \% adult malformation.

Bioassay

The biological experiments were conducted separately with Teflubenzuron, $B$. thuringiensis or $S$. marcescens and in combination to study the sequential combined effect of the tested pesticides. In the individual experiments, castor oil leaves treated with the determined $\mathrm{LC}_{50}$ of each of the two tested compounds were offered newly ecdysis second instar larvae, Teflubenzuron or $B$. thuringiensis Var. kurstaki. for $24 \mathrm{~h}$., after that time larvae were reared on untreated leaves. Whereas, in case of S.marcescens, sawdust treated with the determined $\mathrm{MC}_{50}$ was offered to the late $6^{\text {th }}$ instar larvae to pupate on it. In the sequential expriments, the combined effect of $S$. marcescens either with B. thuringiensis (Bt/Serr) or Teflubenzuron (Teflu /Serr) were carried out by treatment of the $2^{\text {nd }}$ instar larvae with the obtained $\mathrm{LC}_{50}$ either of $B$. thuringiensis or Teflubenzuron then, at the end of larval stage, the late $6^{\text {th }}$ instar larvae were allowed to pupate on

Table 1. Toxicity values of Bacillus thuringiensis and Teflubenzuron to Spodoptera littoralis treated as $2^{\text {nd }}$ instar larvae

\begin{tabular}{lllllcccc}
\hline No & Line name & $\mathbf{L C}_{\mathbf{5 0}}$ & $\mathbf{L C}_{\mathbf{9 0}}$ & Slope & RR & Index & Lower limit & Upper limit \\
\hline 1 & Teflubenzuron & 0.114 & 0.736 & 1.581 & 1 & 100 & 0.084 & 0.155 \\
2 & bacillus thuringiens & 168.89 & 2313.30 & 1.128 & 1481.54 & 0.067 & 138.176 & 203.083 \\
\hline \multicolumn{2}{l}{ Index compared with teflubenzuron } & \multicolumn{2}{l}{ Resistance Ratio (RR) compared with teflubenzuron } & & &
\end{tabular}

Index compared with teflubenzuron $\quad$ Resistance Ratio (RR) compared with teflubenzuron sawdust treated with $S$. marcescens at the $\mathrm{MC}_{50}$. Three replicates were used each replicate include 120 larvae. Pupal samples for biochemical assay were collected after 2, $4,6,8,10,12$ and 14 days of prepupation.

\section{Biochemical assay}

Preparation of haemogenate samples of S.littoralis

The collected pupae were homogenized in distilled water at $500 \mathrm{rpm}$ using a Teflon homogenizer (MECHIANIKA PRECYZYJNA Warszawa type MPN309-Poland) - surrounded with a jacket of crushed ice for 3 minutes. Homogenates were collected in cold tubes (on ice) previously coated with crystals of phenylthiourea to prevent melanization, then centrifuged at $6000 \mathrm{rpm}$ for 10 min at $5^{\circ} \mathrm{C}$ using (BECKMAN GS-6R Centrifuge). After centrifugation, the supernatant fluid was divided into small aliquots $(0.5 \mathrm{ml})$ and stored at $-20{ }^{\circ} \mathrm{C}$ until analysis of enzyme activities and determination of main component. Three replicates were carried out for each biochemical determination.

\section{Determination of enzymes activities}

The aspartate aminotransferase (AST/GOT) activity and alanine aminotransferase (ALT/GPT) activity (Transaminases activity) were determined according to (Reitman and Frankle, 1957)

\section{Statistical analysis:}

The results of biochemical determinations were pooled from triplicate determinations. The results were analyzed by one - way analysis of variance (ANOVA) using constant statistical software (cohort software, Berkeley). When the ANOVA statistics were significant (P $<0.01)$, means were compared by the Duncan's multiple range test.

\section{RESULTS}

Toxicity of Bacillus thuringiensis and Teflubenzuron and adult malformation caused by Serratia marcescens to Spodoptera littoralis

In Table (1) the toxicity of Teflubenzuron or $B$. thuringiensis to the $2^{\text {nd }}$ instars of $S$. littoralis is evaluated by determination of toxicity parameters $\left(\mathrm{LC}_{50}\right)$ and toxicity index). Based on $\mathrm{LC}_{50}$ values, it is obvious that both agents caused considerable toxic effects against the $2^{\text {nd }}$ larvae of $S$. littoralis particularly in case of Teflubenzuron which had drastical toxic effects comparing to B.thuringiensis toxicity. The toxicity index indicates that Teflubenzuron was about 1481.54 times as toxic as B.thuringiensis. The $\mathrm{LC}_{50}$ of Teflubenzuron is $0.114 \mathrm{ppm}$ whereas it is $168.89 \mathrm{ppm}$ in case of treatment with B.thuringiensis, On the other hand, data presented in Table (2) revealed that the minimal concentration caused $50 \%$ adult malformation $\left(\mathrm{MC}_{50}\right)$ to the late $6^{\text {th }}$ instars of S.littoralis in sawdust was treated with $S$. marcescens was $3.09 \times 108 \mathrm{cfu} / \mathrm{ml}$. 
Table 2. Serratia marcescens minimal concentration which causes $\mathbf{5 0 \%}$ adult malformation to Spodoptera littoralis (Boisd).

\begin{tabular}{|c|c|c|c|c|}
\hline Agent & $* \mathrm{MC}_{50}{ }^{* *}(\mathrm{cfu} / \mathrm{ml})$ & 95\% Fiducial Limits & Slope \pm S.E. & $\mathbf{X}_{(\mathbf{d f})}^{2}$ \\
\hline S. marcescens & $3.09 \times 10^{\circ}$ & $3.81 \times 10^{9}$ & $0.29 \pm 0.055$ & $0.966_{(4)}$ \\
\hline
\end{tabular}

Effect of treatments on aspartate aminotransferase activity in pupal stage

From results presented in Table (3), it could be seen that aspartate aminotransferase (AST) activity of $S$. littoralis pupae treated with $S$. marcescens have the same trend during pupation time as control. Thus, it was decreased from 46.677 to 2.436 and from 22.184 to 2.565 $\mu \mathrm{g}$ oxaloacetate/ $\mathrm{min} / \mathrm{g}$ body weight with untreated pupae and treated pupae with $S$. marcescens, respectively. In addition, $S$. marcescens caused significant decrease at $2^{\text {nd }}$, $4^{\text {th }}$ and $10^{\text {th }}$ days $(-52.47 \%,-28.14 \%$ and $-22.17 \%$, respectively), while, significant increase at $8^{\text {th }}$ day $(50.83 \%)$ of pupation was found relative to control. Also, treatment with $B$. thuringiensis alone revealed significant decreases through pupal stage (maximum of $-84.62 \%$ at first time) except at $6^{\text {th }}$ and $8^{\text {th }}$ days of pupation $(70.21 \%$ and $62.40 \%$ increase). The highest levels of aspartate aminotransferase activities were clearly found in individual treatment with Teflubenzuron. On the other hand, when the sequential combined effect treatment $B$. thuringiensis/ $S$. marcescens $(B t / S m)$ was used, there were more reduction in the activity at $2^{\text {nd }}, 4^{\text {th }}$ and $10^{\text {th }}$ days $(-72.11 \%$,
$-50.66 \%$ and $-39.62 \%$, respectively) than that of $S$. marcescens and generally, during the pupal stage, the sequential $B t / S m$ had less effect than individual $B$. thuringiensis . The sequential combined effect treatment Teflubenzuron/ $S$. marcescens (Teflu/Sm) gave significant decreases during pupal stage whereas there was significant increase $(221.28 \%)$ just at $6^{\text {th }}$ day which was higher than that of individual treatment with Teflubenzuron $(197.87 \%$ ) but still clearly less effective at the other times as compared to control. Generally, the effect of Teflu/Sm was higher than individual $S$. marcescens but less effective than individual Teflubenzuron.

Effect of treatments on alanine aminotransferase activity in pupal stage

Data presented in Table (4), show changes in alanine aminotransferase (ALT)activity during pupal of $S$. littoralis treated with $S$. marcescens at concentration causes $50 \%$ malformation $\left(\mathrm{MC}_{50}\right), \quad \mathrm{LC}_{50}$ of $B$. thuringiensis, Teflubenzuron and their sequential combined effects treatments of both $B$. thuringiensis/ S.marcescens $(B t / S m)$ and Teflubenzuron/S.marcescens.

Table 3.Changes of aspartate aminotransferase activity in pupal stage of Spodoptera littoralis treated with Serratia marcescens $\left(\right.$ at $\left.\mathrm{MC}_{50}\right), B$. thuringiensis and Teflubenzuron $\left(\right.$ at $\mathrm{LC}_{50}$ ) and their sequential combined effects (Mean \pm SE).

\begin{tabular}{|c|c|c|c|c|c|c|c|c|c|c|c|}
\hline \multirow[b]{2}{*}{$\begin{array}{l}\text { Time - } \\
\text { in day }\end{array}$} & \multicolumn{11}{|c|}{$\begin{array}{l}\text { Aspartate aminotransferase activity ( } \mu \text { g oxaloacetate } / \mathrm{min} / \mathrm{g} \text { body weight) }(\mathrm{Mean} \pm \mathrm{SE}) * \\
\text { Treatments }\end{array}$} \\
\hline & Control & S. marcescens & $\begin{array}{c}\% \\
+ \text { or - } \\
\text { control }\end{array}$ & $\begin{array}{c}\text { B. } \\
\text { thuringiensis }\end{array}$ & $\begin{array}{c}\% \\
+ \text { or - } \\
\text { control }\end{array}$ & Teflubenzuron & $\begin{array}{c}\% \\
+ \text { or - } \\
\text { control }\end{array}$ & $\mathrm{Bt} / \mathrm{Sm}$ & $\begin{array}{c}\% \\
+ \text { or - } \\
\text { control }\end{array}$ & Teflu / Sm & $\begin{array}{c}\% \\
+ \text { or - } \\
\text { control }\end{array}$ \\
\hline & $\mathrm{c}$ & gh & & st & & $\mathrm{c}$ & & $\mathrm{mn}$ & & $\mathrm{i}$ & \\
\hline 2 & $46.677 \pm$ & $22.184 \pm$ & & $7.181 \pm$ & & $45.779 \pm$ & & $13.016 \pm$ & & $19.556 \pm$ & \\
\hline & $\begin{array}{c}1.797 \\
\text { ij }\end{array}$ & $\begin{array}{c}0.899 \\
\operatorname{lm}\end{array}$ & -52.47 & $\begin{array}{c}0.170 \\
\text { nop }\end{array}$ & -84.62 & $\begin{array}{c}1.238 \\
\mathrm{c}\end{array}$ & -1.92 & $\begin{array}{c}0.449 \\
\text { pqr }\end{array}$ & -72.11 & $\begin{array}{c}0.670 \\
\text { nop }\end{array}$ & -58.10 \\
\hline 4 & $19.361 \pm$ & $13.913 \pm$ & & $10.836 \pm$ & & $46.164 \pm$ & & $9.553 \pm$ & & $11.220 \pm$ & \\
\hline & $\begin{array}{c}0.560 \\
\text { mno }\end{array}$ & $\begin{array}{l}0.501 \\
\operatorname{lm}\end{array}$ & -28.14 & $\begin{array}{l}0.280 \\
\text { hi }\end{array}$ & -44.03 & $\begin{array}{l}1.420 \\
\mathrm{e}\end{array}$ & 138.44 & $\begin{array}{l}0.340 \\
\mathrm{kl}\end{array}$ & -50.66 & $\begin{array}{l}0.390 \\
\mathrm{~d}\end{array}$ & -42.05 \\
\hline 6 & $\begin{array}{c}12.054 \pm \\
0.340 \\
\mathrm{kl}\end{array}$ & $\begin{array}{c}13.657 \pm \\
0.556 \\
\text { fg }\end{array}$ & 13.30 & $\begin{array}{c}20.517 \pm \\
0.670 \\
f\end{array}$ & 70.21 & $\begin{array}{c}35.905 \pm \\
1.141 \\
\mathrm{a}\end{array}$ & 197.87 & $\begin{array}{c}15.523 \pm \\
0.560 \\
\text { opqr }\end{array}$ & 28.78 & $\begin{array}{c}38.727 \pm \\
1.408 \\
\mathrm{jk}\end{array}$ & 221.28 \\
\hline 8 & $\begin{array}{c}15.516 \pm \\
0.560 \\
\operatorname{lm}\end{array}$ & $\begin{array}{c}23.403 \pm \\
0.892 \\
\text { opq }\end{array}$ & 50.83 & $\begin{array}{c}25.198 \pm \\
0.729 \\
\text { nop }\end{array}$ & 62.40 & $\begin{array}{c}72.901 \pm \\
2.696 \\
b\end{array}$ & 369.84 & $\begin{array}{c}10.259 \pm \\
0.390 \\
\text { rs }\end{array}$ & -33.88 & $\begin{array}{c}17.119 \pm \\
0.619 \\
\text { pqrs }\end{array}$ & 10.33 \\
\hline 10 & $\begin{array}{c}13.593 \pm \\
0.449\end{array}$ & $\begin{array}{c}10.579 \\
0.401\end{array}$ & -22.17 & $\begin{array}{c}10.900 \pm \\
0.340\end{array}$ & -19.81 & $\begin{array}{c}60.077 \pm \\
1.773\end{array}$ & 341.97 & $\begin{array}{c}8.207 \pm \\
0.231\end{array}$ & -39.62 & $\begin{array}{c}9.233 \pm \\
0.294\end{array}$ & -32.08 \\
\hline 12 & $\begin{array}{c}\text { qrs } \\
8.333 \pm \\
0.340\end{array}$ & $\begin{array}{c}\text { pqrs } \\
9.297 \pm \\
0.280\end{array}$ & 11.57 & $\begin{array}{c}\text { uvw } \\
4.424 \pm \\
0.111\end{array}$ & -46.91 & $\begin{array}{c}\mathrm{c} \\
45.074 \pm \\
1.009\end{array}$ & 440.91 & $\begin{array}{c}\text { vwx } \\
3.078 \pm \\
0.111\end{array}$ & -63.06 & $\begin{array}{c}\text { tu } \\
5.835 \pm \\
0.170\end{array}$ & -29.98 \\
\hline $\begin{array}{l}14 \\
\text { LSD }\end{array}$ & $\begin{array}{c}\text { Wx } \\
2.436 \pm \\
0.340\end{array}$ & $\begin{array}{c}\text { vwx } \\
2.565 \pm \\
0.170\end{array}$ & 5.30 & $\begin{array}{c}\text { uvw } \\
4.681 \pm \\
0.170\end{array}$ & 92.16 & $\begin{array}{c}\text { nop } \\
11.028 \pm \\
0.390 \\
2.3131\end{array}$ & 352.71 & $\begin{array}{c}\mathrm{x} \\
1.795 \pm \\
0.064\end{array}$ & -26.31 & $\begin{array}{c}\text { tuv } \\
4.873 \pm \\
0.170\end{array}$ & 100.04 \\
\hline
\end{tabular}

*Means with the same letter(s) are not significantly different. $(\mathrm{P}<0.05)$; LSD : least significant difirence.

$B t / S m$ : B. thuringiensis / S. marcescens; Teflu / S. $m$ : Teflubenzuron / S. marcescens

$\mathrm{MC}_{50}$ : concentration caused $50 \%$ adult malformation.

The obtained data showed that, the treatment with S.marcescence exhibited significant increases in alanine aminotransferase activity during pupation times (maximum of $168.63 \%$ and $114.56 \%$ at $10^{\text {th }}$ and $14^{\text {th }}$ days, respectively)

except at $2^{\text {nd }}$ and $8^{\text {th }}$ days $(-30.25 \%$ and $-34.54 \%$, respectively). Also, B. thuringiensis caused a stimulating effect on alanine aminotransferase activity by about $246.42 \%$ and $123.19 \%$ at $6^{\text {th }}$ and $8^{\text {th }}$ days of pupation, respectively. 
Table 4.Changes of alanin aminotransferase activity in pupal stage of Spodoptera littoralis treated with Serratia marcescens at $\left(\mathrm{MC}_{50}\right)$, Bacillus thuringiensis and Teflubenzuron (at $\left.\mathrm{LC}_{50}\right)$ and their sequential combined effects (Mean $\pm \mathrm{SE})$.

\begin{tabular}{|c|c|c|c|c|c|c|c|c|c|c|c|}
\hline \multirow{4}{*}{$\begin{array}{c}\text { Time in } \\
\text { day }\end{array}$} & \multicolumn{11}{|c|}{ Alanin aminotransferase activity ( $\mu$ g pyruvate $/ \min / \mathrm{g}$ body weight) $(\mathrm{Mean} \pm \mathrm{SE}) *$} \\
\hline & \multirow[b]{3}{*}{ Control } & \multirow[b]{3}{*}{ S. marcescens } & \multicolumn{6}{|c|}{ Treatments } & \multirow{3}{*}{$\begin{array}{c}\% \\
+ \text { or - } \\
\text { control }\end{array}$} & \multirow[b]{3}{*}{ Teflu / Sm } & \multirow{3}{*}{$\begin{array}{c}\% \\
+ \text { or }- \\
\text { control }\end{array}$} \\
\hline & & & $\%$ & & $\%$ & & $\%$ & & & & \\
\hline & & & $\begin{array}{c}+ \text { or - } \\
\text { control }\end{array}$ & B. thuringiensis & $\begin{array}{c}+ \text { or - } \\
\text { Control }\end{array}$ & Teflubenzuron & $\begin{array}{c}+ \text { or - } \\
\text { control }\end{array}$ & $B t / S m$ & & & \\
\hline \multirow{2}{*}{2} & gh & $\mathrm{k}$ & & $\operatorname{lm}$ & & $\mathrm{e}$ & & $\mathrm{qr}$ & & lmno & \\
\hline & $26.288 \pm 1.003$ & $18.337 \pm 0.571$ & -30.25 & $12.118 \pm 0.294$ & -53.90 & $32.251 \pm 1.178$ & 22.68 & $7.117 \pm 0.222$ & -72.93 & $11.028 \pm 0.357$ & -58.05 \\
\hline \multirow{2}{*}{4} & $\operatorname{lm}$ & $\mathrm{j}$ & & $\operatorname{lm}$ & & $\mathrm{f}$ & & $\operatorname{lmn}$ & & nop & \\
\hline & $13.206 \pm 0.560$ & $21.543 \pm 0.619$ & 63.13 & $13.144 \pm 0.390$ & -0.47 & $28.724 \pm 1.009$ & 117.51 & $11.477 \pm 0.231$ & -13.09 & $9.682 \pm 0.280$ & -26.68 \\
\hline \multirow{2}{*}{6} & rs & $\mathrm{pq}$ & & $\mathrm{k}$ & & $\operatorname{lm}$ & & Imno & & $\mathrm{k}$ & \\
\hline & $5.386 \pm 0.222$ & $7.950 \pm 0.340$ & 47.60 & $18.658 \pm 0.401$ & 246.42 & $12.182 \pm 0.390$ & 126.18 & $10.969 \pm 0.222$ & 103.66 & $16.350 \pm 0.510$ & 203.56 \\
\hline \multirow{2}{*}{8} & $\operatorname{lm}$ & $\mathrm{pq}$ & & $\mathrm{fg}$ & & ij & & pqr & & $\mathrm{qr}$ & \\
\hline & $12.439 \pm 0.340$ & $8.143 \pm 0.280$ & -34.54 & $27.763 \pm 0.971$ & 123.19 & $23.146 \pm 0.789$ & 86.08 & $7.438 \pm 0.231$ & -40.20 & $7.053 \pm 0.231$ & -43.30 \\
\hline \multirow{2}{*}{10} & mno & $\mathrm{f}$ & & $\operatorname{lm}$ & & $\mathrm{c}$ & & opq & & opq & \\
\hline & $10.836 \pm 0.390$ & $29.109 \pm 1.051$ & 168.63 & $12.759 \pm 0.280$ & 17.75 & $46.485 \pm 1.250$ & 328.99 & $8.912 \pm 0.170$ & -17.76 & $8.912 \pm 0.280$ & -17.76 \\
\hline \multirow{2}{*}{12} & $\mathrm{k}$ & hi & & $\mathrm{qr}$ & & $\mathrm{d}$ & & $\mathrm{s}$ & & 1 & \\
\hline & $18.332 \pm 0.679$ & $25.070 \pm 0.899$ & 36.76 & $6.925 \pm 0.222$ & -62.22 & $43.407 \pm 1.687$ & 136.78 & $3.142 \pm 0.064$ & -82.86 & $13.272 \pm 0.294$ & -27.60 \\
\hline \multirow{2}{*}{14} & $\mathrm{f}$ & $\mathrm{b}$ & & pqr & & $\mathrm{a}$ & & $\mathrm{s}$ & & $\mathrm{d}$ & \\
\hline & $29.494 \pm 1.119$ & $63.283 \pm 2.004$ & 114.56 & $7.373 \pm 0.280$ & -75.00 & $88.609 \pm 3.106$ & 200.43 & $3.078 \pm 0.111$ & -89.56 & $42.830 \pm 1.009$ & 45.22 \\
\hline LSD & 2.4103 & & & & & & & & & & \\
\hline
\end{tabular}

*Means with the same letter(s) are not significantly different. $(\mathrm{P}<0.05) \quad$; LSD : least significant difirence.

Bt/Sm : B. thuringiensis /S. marcescens ; Teflu / S.m : Teflubenzuron / S. marcescens

$\mathrm{MC}_{50}$ : concentration caused $50 \%$ adult malformation.

Whereas Significant decreases at $2^{\text {nd }}, 12^{\text {th }}$ and $14^{\text {th }}$ days of pupation were recorded. Teflubenzuron clearly induced high levels of alanine aminotransferase activity during pupal stage particularly at the last three times $(328.99 \%, 136.78 \%, 200.43 \%$, respectively). Thus, Teflubenzuron had an effect on alanine aminotransferase activity higher than $B$. thuringiensis which was effective than S.marcescence . On the other hand, in the sequential combined effect treatments, Bt/Sm exhibited more decreasing effect at both first and last two times of pupation $(-72.93 \%,-82.86 \%$ and $-89.56 \%$, respectively ) than that of individual treatment with $B$. thuringiensis ($53.90 \%,-62.22 \%$ and $-75.00 \%$, respectively) . Teflu $/ \mathrm{Sm}$ caused significant reduction in alanine aminotransferase activity except at $4^{\text {th }}$ and $6^{\text {th }}$ days, where there is significant increase. The increase at $6^{\text {th }}$ day $(203.56 \%)$ was higher than that of individual Teflubenzuron $(126.18 \%)$ or individual $S$. marcescens $(47.60 \%)$. Generally, individual Teflubenzuron had the highest effect.

\section{DISCUSSION}

By studying the Toxicity of Bacillus thuringiensis, Teflubenzuron and adult malformation caused by Serratia marcescens to $2^{\text {nd }}$ instar larvae Spodoptera littoralis noticeable that, the $\mathrm{LC}_{50}$ value of chitin synthesis inhibitor (CSI) Teflubenzuron was similar to that obtained by Thabit (2011) who recorded $\mathrm{LC}_{50}$ of $0.177 \mathrm{ppm}$ for Teflubenzuron towards $2^{\text {nd }}$ instar larvae of $S$. littoralis. Teflubenzuron in the present study had drastical toxic effect comparing to B.thuringiensis, this was similar to Abd El-Aziz (2007) who found that Lufenuron (CSI) had drastical toxic effect comparing to B.thuringiensis on $2^{\text {nd }}$ instar larvae of $S$. littoralis. The obtained results are supported by the work of Seleem (2012) who reported that the $\mathrm{LC}_{50}$ value of $B$. thuringiensis var Kurstaki was 242.297 ppm against the $2^{\text {nd }}$ instar larvae of $S$. littoralis . On the other hand, the minimal concentration which causes $50 \%$ adult malformation of $S$. littoralis was similar to Tolba (2006) and EL-Sheikh et al.(2005) working on Agrotis ipsilon.

The data showed conspicuous changes in alanine aminotransferase (ALT)activity and aspartate aminotransferase (AST) activity during pupal of $S$. littoralis treated with $S$. marcescens at concentration causes $50 \%$ malformation $\left(\mathrm{MC}_{50}\right), \mathrm{LC}_{50}$ of $B$. thuringiensis, Teflubenzuron and their sequential combined effects treatments of both B. thuringiensis/ S.marcescens (Bt/Sm) andTeflubenzuron/S.marcescens.

The results obtained either for $S$. marcescens or Teflubenzuron treatment are similar to those of Tolba (2006) who found decreases in aspartate aminotransferase activity during pupal stage of $A$. ipsilon treated with $S$. marcescens in contrast to increases with Flufenoxuron, Moreover, ALT (alanine aminotransferase) was increased in both treatments. Abou-Taleb et al.(2009) recorded an increase in AST and ALT activity of $S$. littoralis larvae as a result of emamectin benzoate treatment. In another study, Ramaswamy et al. (1999) reported that the activity of these enzymes was elevated when Sorotherodon mossambicus (Peters) had been exposed to Carbaryl.

In insects, the amino transferases are the key enzymes in the formation of non-essential amino acids, in the metabolism of waste nitrogen products and in gluconeogenesis Pant and Kumar, 1980. The same authors stated that the change in transaminase levels have been correlated with anabolism or catabolism of protein. Maintenance of the balanced "amino acid pool" in insects is the result of various biochemical reactions carried out by a group of enzymes called amino-transferases (Meister, 1957). Transaminases (ALT and AST) enzymes help in the production of energy and serve as a strategic link between the carbohydrates and protein metabolism and are known to be altered during various physiological and pathological conditions (Eltebari et al., 2005). The varying effects on the level of GPT (glutamate pyruvate aminotransferase) activity in decreasing or increasing levels may be due to 
the effect on the synthesis or functional levels of this enzyme directly or indirectly by altering the cytomorphology of the cells (Nath, 2000).The increasing GOT (glutamate oxaloacetate aminotransferase ) activity, generally after treatment suggest the mobilization of amino acids during the insecticidal stress exerted by certain toxic components to meet the energy demands (Zeba and Khan, 1995). The decrease in AST and ALT may be attributed to the binding of the tested compounds with protein that leads to inhibition in aminotransferases activity which is known to be intimately related to protein synthesis (El-Sheikh et al. 2005). Also, El-Shershaby et al. (2008) found fluctuated changes in the activity of GPT and GOT of S.littoralis larvae infected with $B$. thuringiensis. , GOT slightly increased after 2 days and then decreased at 5days post-treatment. The GPT activity was clearly decreased after 48 and 72 hrs of treatment than in untreated; GPT enzyme activity detected the highest positive changes. They suggested that this may be attributed to the occurrence of reversible binding between pesticides and enzymatic site of action on the enzyme surface. (AbouTaleb et al., 2015) suggested that the changes of ALT and AST activity in the $S$. littoralis larvae following lufenuron and chlorfluazuron exposures showed adaptive elevation in the activity of the two aminotransferase enzymes, thereby, probably aiding gluconeogenesis through transamination of glucogenic amino acids to meet the energy demand under lufenuron and chlorfluazuron toxicity. Also Zibaee et al. (2011) mentioned that AST and ALT activity significantly increased in Eurygaster integricps after exposure to pyriproxyfen. They concluded that possible damages of this insecticide to haemocytes and fat bodies are the reason in elevation of their activity. This correlation could be attributed to regeneration of haemocytes by hematopoietic organs and fat bodies that definitely needs to different amino acids prepared by transamination process.

\section{REFERENCES}

Abd El-Aziz, M.M. (2007). Controlling of the cotton leafworm, $S$. littoralis (Boisd.) by using environmentally safe (nontraditional) methods. M.Sc. Thesis, Dep. Of Environ. Agric. Sci., Institute of Environ. Studies and Research AinShams Univ., Egypt. pp: 38-41.

Abo El-Ghar, G.E.S.; H.S.A. Radwan Z.A. El-Bermawy and L.T.M. Zidan (1994). Histopatholgoical effects of abamectin, thuringiensin and diflubenzuron on the midgut of Spodoptera littoralis (Lepidoptera: Noctuidae) larvae. Bull. Ent. Soc.Egypt, 21: 41-52.

Abou-Taleb,H. K.,Zahran,H.M. and GAD,A.A. (2015).Biocmemical and Physiological Effects of lufenuron and Chlorfluazuron on Spodoptera littoralis (Boisd.) (Lepidoptera Noctuidae) J. Entomol. 12 (2):77-86.
Abou-Taleb, H.K., A.S.A Saad, H.A. Mesbah, S.M. Abdel Rahman and D.A. El-Deeb, (2009). Toxicity of emamectin benzoate against laboratory and field strains of cotton leaf worm with reference to its effects on the AST, ALT and ALP activity. Proceedings of the $6^{\text {th }}$ international Symposium of Mediterranean Group on Pesticide Research, October 27-29, 2009, Cairo, Egypt.

El-Sheikh, T.A.; A.A. Abdel-Khalik; A.A. Farghali and A.E. Abdel-Aal (2005).Biochemical and histological effects of Flufenoxuron and two biocides on the cotton leafworm, Spodoptera littoralis (Boisd.). Egypt J. Agric. Res. 2 (2): 799809.

El-Shershaby, M.; Farag, N. A. and Ah med, A. A. I. (2008). Impact of Bacillus thuringiensis on protein content and enzymes activity of Spodoptera littoralis . Res. J. of Agric. and Biol. Sci.,4(6): 861865.

Etebari, K.; Mirhodeini, S. Z. and Matindoost, L., (2005). A study on intraspecific biodiversity of eight groups of silkworm (Bombyx mori) by biochemical markers. Insect Science, 12: 87-94.

Finney, D.J. (1971).Probit Analysis, A statistical treatment of the sigmoid response curve.7th Ed., Cambridge Univ. Press, Cambridge, England.

Magd El-Din and El-Gengaihi, S.E. (2000). Joint action of some botanical extracts against the Egyptian cotton leafworm Spodoptera littoralis Bosid (Lepidoptera: Noctuidae). Egypt. J. Biol. P. Cont. 10 (1): 51-56.

Meister, A.(1957) Biochemistry of the amino Acids, Academic Press, New York.

Nath, B. S. (2000). Changes in carbohydrate metabolism in hemolymph and fat body of the silkworm, Bombyx mori L., exposed to organophosphorus insecticides. Pestic. Biochem. Physiol., 68: 127-137.

Pant R. and Kumar S. (1980). Significance of some enzymes and metabolites during aging of the dipteran fleshfly, Sarcophaga ruficornis. Curr. Sci. 49, 10-13.

Ramaswamy, M., P. Thangavel and N.P. Selvam, (1999). Glutamic Oxaloacetic Transaminase (GOT) and Glutamic pyruvicTransaminase (GPT) enzyme activities in different tissues of Sarotherodon massambicus (Peters) exposed to acarbamate pesticide, Pestic.Sci., 55:1217-1221.

Reitman, S. and Frankel S. A. (1957). Colorimetric method for the determination of serum glutamic oxalacetic and glutamic pyruvic transaminases. $\mathrm{Am}$ J Clin Pathol. Jul;28(1):56-63

Sarto, I. and Monteys, V. (1988). Lepidopterous species recognised as pests in Catalina and the affected crops. Resumnese I Journadalberica de Lepidopterologia Madrid 19 Nov.

Schmutterer, H. (1985): Which insect bests can be controlled by application of neem seed kernel extracts under field conditions? Z.ang. Ent., 100: 458-475. 
Seleem, R.A.A. (2012). Effect of different handling and storage coditions of some bio-insecticides on their toxicological and bio-chemical activity. M.Sc. Thesis, Fac. Agric.,Ain Shams Univ.,126-130.

Sun, Y. P. (1950). Toxicity index-An improved method of comparing the relative toxicity of insecticides. J. Econ. Entomol., 43: 45-53.

Thabit, A. (2011). Effect of insect growth regulators combined with Nuclear Polyhedrosis Virus treatments against $S$. littoralis (Boisd.). M.Sc. Thesis, Fac. of Agric. Cairo, Univ. 55-61.

Tolba, H.I. (2006). Biochemical studies on Serratia marcescens for controlling the black cutworm, Agrotis ipsilon (Huf.) Ph. D. Thesis, Faculty of Agriculture, Cairo University, Egypt. pp. 57-72.

Tunaz, H. and Uygun, N. (2004). Insect growth regulators for insect pest control. Turkish J. Agricultural. Forestry, 28: 337-387.
Zeba A. and Khan M.A. (1995). Effect of fenvalerate on protein and amino acid contents and enzyme activities in the Ostracod, Chrissica halyi. Pestic. Sci., 45, 279-282.

Zibaee, A., I. Zibaee and J.J. Sendi, (2011). A juvenile hormone analog. Pyriproxyfen, affects some biochemical components in the hemolymph and fat bodies of Eurygaster integriceps Puton (Hemiptera: Scutelleridae). Pestic. Biochem. Physiol., 100: 289-298.

\section{التأثير المقارن بين تيفلوينزورن ، باسيلس ثورينجينسيس ، و السراتية الذابلة بثكل فردي ومجتمعة على أنشطة

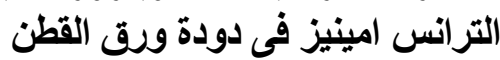

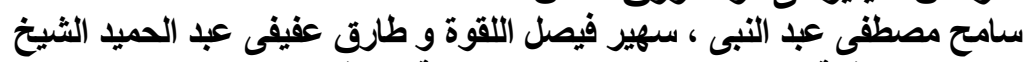 معهد بحوث وقاية النباتات ـ مركز البحوث الزراعية ـ الدقى ـ الجيزة}

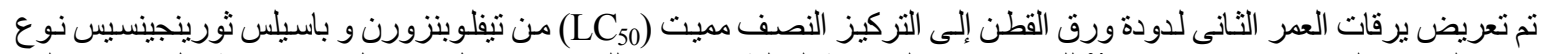

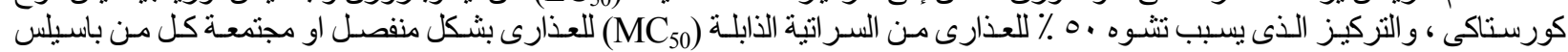

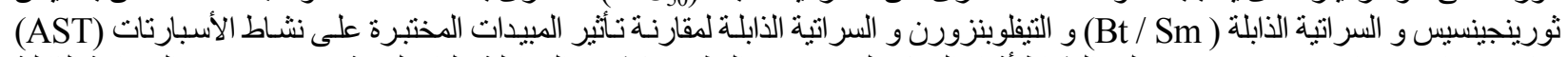

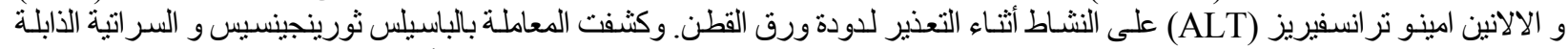

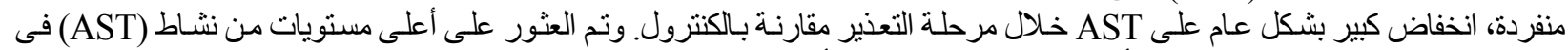

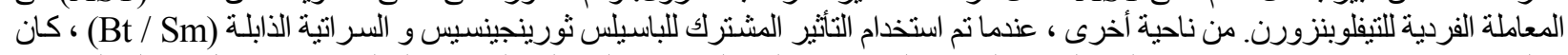

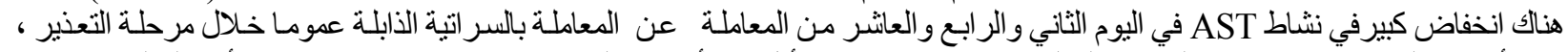

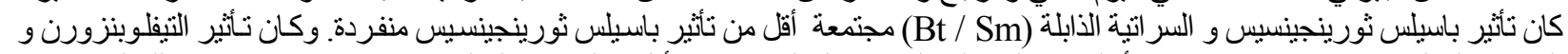

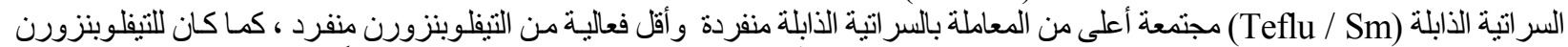

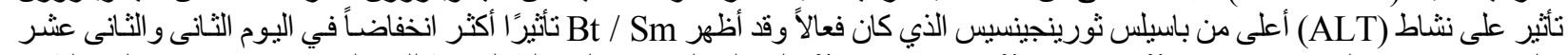

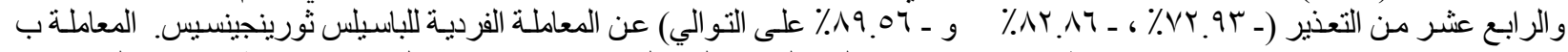

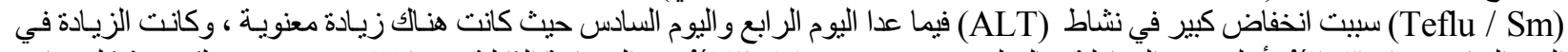

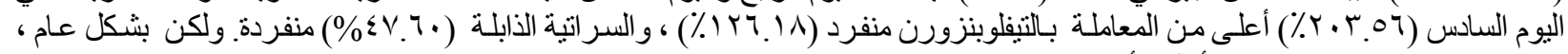
كان Teflubenzuron منفردا الأعلى تأثنير. 